\title{
VERIFICATION OF THE SELECTED PREDICTION METHODS IN SLOVAK COMPANIES
}

\author{
[Verifikácia vybraných predikčných metód na vzorke Slovenských podnikov]
}

\author{
Petra Gundová ${ }^{1}$ \\ ${ }^{1}$ Univerzita Mateja Bela, Ekonomická fakulta, Katedra ekonomiky a manažmentu podniku, \\ Tajovského 10, 97590 Banská Bystrica \\ Email:petra.gundova@umb.sk
}

\begin{abstract}
Nowadays the issue of companies' bankruptcy is very actual topic not only in Slovakia but also abroad. Financial analysts are looking into the possibility to predict of companies crisis by using prediction methods of financial analysis ex-ante. The aim of the article is verification and comparison of results of the selected prediction methods in a group of Slovak companies in year 2009, 2010 and 2011. Group of companies contains six Slovak companies. In the introduction of the article we define the theoretical aspects of prediction methods. Comparison of results of prediction methods and their verification are a major part of the article.
\end{abstract}

Keywords: financial analysis ex-ante, logit model, prediction methods, probit model, verification of prediction methods.

JEL classification: M21

Doručeno redakci: 23.2.2014; Recenzováno: 6.5.2014; 2.6.2014; Schváleno k publikování: 11.2.2015

\section{Úvod}

Podnikatel'ské subjekty sa počas svojej existencie dostávajú do rôznych krízových situácií, ktoré $\mathrm{v}$ prípade ich neriešenia môžu predstavovat' ohrozenie životaschopnosti podniku a v konečnom dôsledku môžu viest' až k ukončeniu jeho podnikatel'skej činnosti. Z analýzy konkurzov od spoločnosti CRIF - Slovak Credit Bureau, s.r.o. vyplýva, že v roku 2012 na Slovensku zbankrotovalo 362 podnikatel'ských subjektov, pričom konkurzmi najviac postihnuté sektory podl'a klasifikácie SK NACE boli G - Vel'koobchod a maloobchod, oprava motorových vozidiel a motocyklov, C - Priemyselná výroba a F - Stavebníctvo. ${ }^{1}$

Zánik podnikatel'ského subjektu ovplyvňuje ekonomiku danej krajiny, spôsobuje rast sociálnych a spoločenských problémov, ktoré sú spojené s rastom nákladov. V dôsledku tejto skutočnosti sa všetci zainteresovaní účastníci pochádzajúci z okolia podniku zaujímajú nielen o vývoj podniku $\mathrm{v}$ minulosti a jeho postavenie $\mathrm{v}$ konkurenčnom prostredí, ale svoj záujem orientujú aj na budúcnost', t.j. na pravdepodobný vývoj podniku v nasledujúcich rokoch. Snažia sa odpovedat' na otázku, či analyzovaný podnik v budúcnosti nebude stratový, resp. či dokonca $\mathrm{v}$ dôsledku negatívnych výsledkov hospodárenia nedôjde $\mathrm{k}$ ukončeniu jeho činnosti.

Ciel’om predloženého príspevku je na vybranej vzorke šiestich slovenských podnikov verifikovat výsledky zvolených metód predikcie. $Z$ vy̌šsie uvedeného dôvodu sa $v$ nami analyzovanom súbore podnikov nachádzajú najmä priemyselné podnikatel'ské subjekty. $\mathrm{Na}$ verifikáciu využijeme sekundárne údaje, ktoré sú už spracované do podoby absolútnych charakteristík, pričom budeme vychádzat' z účtovných výkazov analyzovaných podnikov z roku 2011. Pred samotnou verifikáciou bude uskutočnená komparácia výsledkov vybraných predikčných metód $\mathrm{v}$ troch po sebe nasledujúcich rokoch, a to konkrétne v rokoch 2009

\footnotetext{
${ }^{1}$ http://www.cribis.sk/Home.aspx
} 
až 2011. Zo širokej škály jednoduchých i zložitejších predikčných metód sme sa rozhodli použit' Rýchly test, Altmanovo Z-skóre, Index bonity, Tafflerov bankrotný model, Springate model, Index IN05, model Poznański, model Virag a Hajda, Ohlsonov model a Zmijewski model.

Predložený príspevok pozostáva z dvoch hlavných na seba nadväzujúcich kapitol. V prvej kapitole komplexne definujeme teoretické východiská predikčných metód, priblížime hlavné dôvody zvolenej klasifikácie vybraných desiatich metód predikcie, ktoré následne charakterizujeme. Kl'účovou čast’ou predloženého príspevku je jeho druhá kapitola, ktorá prezentuje výstupy sekundárneho empirického výskumu. V úvode danej kapitoly zobrazíme výsledky vypočítaných predikčných metód v účtovnom období 2009, 2010 a 2011, pričom pre dané obdobie sme sa rozhodli z dôvodu vypuknutia hospodárskej krízy v rokoch 2008-2009, t.j. sledujeme predikčnú schopnost' metód v období globálnej krízy. Výsledky predikcie budú navzájom medzi sebou porovnávané, pričom na komparáciu predikčných metód nadväzuje overenie ich vypovedacej (predikčnej) schopnosti v roku 2011, t.j. verifikácia vybraných predikčných metód.

\section{Teoretické vymedzenie predikčných metód}

Pred praktickou aplikáciou predikčných metód vo vybraných šiestich slovenských podnikatel'ských subjektoch je potrebné uviest' ich stručné teoretické vymedzenie. Predikčné metódy finančnej analýzy ex-ante vychádzajú z predpokladu, že v podniku dochádza už dlhšie časové obdobie pred vznikom krízovej situácie k určitým anomáliám, v ktorých sú obsiahnuté symptómy budúcich problémov charakteristické práve pre ohrozené podniky. Úradníček (2010) uvádza, že osobitne sa tieto symptómy prejavujú vo výkonnosti podniku, pričom spravidla majú podobu rozdielnej úrovne, variability a dynamiky vývoja vybraných finančných ukazovatel'ov odzrkadl'ujúcich finančno-ekonomický stav sledovaného podniku.

Z bohatého aparátu metód finančnej analýzy ex-ante sme sa rozhodli pre desat' metód predikcie, ktoré môžeme rozdelit' do nasledovných štyroch kategórií:

1. v podnikatel'skej praxi najpoužívanejšie metódy predikcie,

2. v odbornej literatúre a podnikatel'skej praxi menej známe predikčné metódy,

3. metódy predikcie pochádzajúce $z$ krajín Vyšehradskej štvorky,

4. logit a probit modely.

Do prvej skupiny sme sa rozhodli zaradit' metódy predikcie, ktorá sú na základe výsledkov predchádzajúcich empirických výskumov v praxi slovenských podnikatel'ských subjektov najpoužívanejšie. Konkrétne išlo o Rýchly test, Altmanovo Z-skóre a Index bonity, pričom tieto metódy môžeme označit’ aj ako všeobecne známe metódy finančnej analýzy ex-ante.

Do druhej kategórie predikčných metód sme zaradili Tafflerov bankrotný model (TBM) a Springate model, s ktorými sa v literatúre a podnikatel'skej praxi stretávame iba ojedinele. Obidva modely vychádzajú z viacrozmernej diskriminačnej analýzy.

Pri aplikácii predikčných metód je potrebné prihliadat' na skutočnost', že metódy boli skonštruované v odlišnom prostredí a sú založené na báze údajov zo špecifického finančného, legislatívneho i informačného prostredia. Dané prostredie sa svojimi parametrami výrazne odlišuje od prostredia, v ktorom pôsobia podnikatel'ské subjekty z krajín Vyšehradskej štvorky. V týchto krajinách sa stretávame s modifikovanými metódami finančnej analýzy exante, čo je spôsobené aj skutočnost'ou, že ekonomika daných krajín prešla výrazným procesom transformácie. Na základe tejto skutočnosti sme do tretej kategórie metód predikcie 
zaradili Poznański model (Pol'sko), model Virag a Hajda (Mad'arsko) a Index IN05 (Česká republika).

Okrem klasických a v literatúre i podnikatel'skej praxi štandardne známych predikčných metód finančnej analýzy ex-ante použijeme aj Ohlsonov model a Zmijewski model, ktoré patria k tzv. logit a probit modelom. Obidva modely vychádzajú z logistickej regresie, ktorá predstavuje oblúbenú modelovaciu techniku pre predikciu úpadku (default) podniku alebo všeobecne akúkol'vek inú binárnu výstupnú veličinu. Vzhl'adom k vstupným predpokladom sú výstupy logistickej regresie vždy hodnoty v intervale $[0 ; 1]$, resp. $0-100 \%$ (Bardún, 2010, s. 51). Logit a probit modely dokonca v určitých prípadoch dosahujú vyššiu predikčnú schopnost' $v$ porovnaní s viacrozmernou diskriminačnou analýzou. Ich hlavnou výhodou je, že ich aplikácia nevyžaduje splnenie predpokladov, ktoré sa pri viacrozmernej diskriminačnej analýze vyžadujú (napr. normálne rozdelenie ukazovatel'ov, deliaca (rozlišovacia) schopnost' ukazovatel'ov, ich nezávislost', rovnost' kovariančných matíc oboch skupín podnikov).

V nasledujúcom texte uvádzame teoretické vymedzenie vyššie uvedených metód predikcie.

\section{Rýchly test}

Rýchly test (Quick test) patrí k metódam bodového hodnotenia, ktoré hodnoty zvolených finančných ukazovatel'ov transformujú na body pomocou bodových stupníc. Z každej zo štyroch základných oblastí analýzy (analýza financovania podniku, likvidity, rentability a analýzy výsledku hospodárenia) bol zvolený jeden ukazovatel', a to tak, aby bola zabezpečená vyvážená analýza finančnej stability, ako aj výnosovej situácie podniku (Lesáková a kol., 2007, s. 69). Ako charakteristiky finančnej stability boli vybrané podiel vlastného kapitálu (koeficient samofinancovania) a lehota splácania cudzieho kapitálu. Ako charakteristiky výnosnosti podniku sa najčastejšie používajú podiel cash-flow z celkových výkonov (cash-flow v \% z tržieb) a rentabilita celkového kapitálu (ROA). Každému zo štyroch ukazovatel'ov sa priradí určitý počet bodov na základe expertných hodnotiacich stupníc, pričom podnik môže získat' celkový počet bodov v rozmedzí $4-20$ bodov. V prípade Rýchleho testu je ideálne dosiahnut' čo najnižšieho počtu bodov ( $\mathrm{v}$ tomto prípade podnik môže očakávat' v budúcnosti priaznivú finančnú situáciu). Podnikatel'ský subjekt je v budúcnosti ohrozený insolvenciou v prípade dosiahnutia 20 bodov.

\section{Altmanovo Z-skóre}

Profesor E. I. Altman spracoval v roku 1968 štatistické údaje na vzorke náhodne vybraných 66 podnikov, z ktorých 33 prešlo v posledných 20 rokoch konkurzným konaním a 33 podnikov, ktoré dovtedy konkurzné konanie neabsolvovali. V sledovaných súboroch boli podniky (podl'a deklarovaného imania) malé, stredné i relatívne vel'ké. Altman pôvodne pracoval so súborom 22 vybraných finančných ukazovatel'ov (tieto ukazovatele rozdelil do piatich tried - likvidita, rentabilita, zadlženost', platobná schopnost' a aktivita) pre všetkých 66 spoločností, ale jeho ciel'om bolo vybrat' malý počet pomerových ukazovatel'ov, ktoré by mohli najlepšie postihnút' rozdiel medzi firmou v konkurze a zdravou firmou. Altman stanovil diskriminačnú funkciu zvlášt' pre podniky s verejne obchodovatel'nými akciami a zvlášt' pre ostatné podniky, pričom autor vytvoril tiež model pre nevýrobné, obchodné a začínajúce podniky. Altmanovo Z-skóre pre podniky s verejne obchodovatel'nými akciami sa vyčísli podl'a vzt'ahu (Lesáková, 2004):

$$
Z=1,2 * x 1+1,4 * x 2+3,3 * x 3+0,6 * x 4+1,0 * x 5
$$

$\mathrm{x}_{1}=$ čistý prevádzkový kapitál/celkový kapitál,

$\mathrm{x}_{2}=$ nerozdelený zisk/celkový kapitál,

$\mathrm{x}_{3}=($ zisk pred zdanením + úroky $) /$ celkový kapitál,

$\mathrm{x}_{4}=$ trhová hodnota vlastného kapitálu/cudzí kapitál,

$\mathrm{x}_{5}=$ tržby/celkový kapitál. 
V prípade, ak je hodnota Altmanovho Z-skóre vyššia ako 2,99, podnik môže v budúcnosti očakávat' priaznivú finančnú situáciu. Altmanovo Z-skóre nižšie ako 1,81 signalizuje silné finančné problémy podniku v budúcnosti. Termínom šedá zóna (nevyhranená finančná situácia) je označený interval od 1,81 po 2,99 . Altmanovo Z-skóre pre podnikatel'ské subjekty, ktoré nie sú podniky s verejne obchodovatel'nými akciami, má nasledovný tvar:

$$
Z=0,717 * x_{1}+0,847 * x_{2}+3,107 * x_{3}+0,420 * x_{4}+0,998 * x_{5}
$$

Vo vyššie uvedenej rovnici zostávajú ukazovatele nezmenené, menia sa iba ich váhy a takisto klasifikačné podmienky, ktoré sú v tomto prípade:

$Z>2,9$ môžeme predikovat' uspokojivú finančnú situáciu,

$1,23<Z \leq 2,9$,šedá zóna“" nevyhranených výsledkov,

$Z \leq 1,23$ podnik je ohrozený vážnymi finančnými problémami.

\section{Index bonity}

V nemecky hovoriacom ekonomickom prostredí (Nemecko, Švajčiarsko, Rakúsko) sa používa Index bonity (nazývaný tiež indikátor bonity), ktorý je $\mathrm{v}$ daných krajinách nazývaný „Verainfachte Methode“. Index bonity je stále častejšie používanou metódou predikcie finančného vývoja podniku aj na Slovensku, pričom patrí k metódam viacrozmernej diskriminačnej analýzy matematicko-štatistických metód. Výsledná rovnica Indexu bonity pozostáva zo šiestich pomerových ukazovatel'ov a má nasledovný tvar (Nový, 2011):

$$
I B=1,5 * x_{1}+0,08 * x_{2}+10 * x_{3}+5 * x_{4}+0,3 * x_{5}+0,1 * x_{6},
$$

$\mathrm{x}_{1}=$ cash-flow/cudzí kapitál,

$\mathrm{x}_{2}=$ celkový kapitál/cudzí kapitál,

$\mathrm{x}_{3}=$ zisk pred zdanením/aktíva,

$\mathrm{x}_{4}=$ zisk pred zdanením/celkové výkony,

$\mathrm{x}_{5}=$ zásoby/aktíva celkom,

$\mathrm{x}_{6}=$ celkové výkony/celkový kapitál.

Platí, že čím je hodnota Indexu bonity väčšia, tým je finančná situácia a prognóza podnikatel'ského subjektu lepšia. Hodnotiaca stupnica je nasledovná: extrémne zlá (-3 až -2), vel'mi zlá (-2 až -1$)$, zlá ( -1 až 0$)$, určité problémy ( 0 až 1$)$, dobrá (1 až 2$)$, vel'mi dobrá (2 až 3) a extrémne dobrá (nad 3) (Zalai a kol., 2008).

\section{Tafflerov bankrotný model}

Tafflerov bankrotný model bol prvýkrát publikovaný v roku 1977. Jeho autor R. J. Taffler vyvinul lineárny model $\mathrm{s}$ piatimi pomerovými ukazovatel'mi, ktorý bol zdokonalený a modifikovaný. Autor zdôrazňoval skutočnost', že je dôležité, aby boli podniky porovnávané v rámci rovnakého odvetvia, pričom ich odporúčal zaradit' na základe dosiahnutých hodnôt do percentilových skupín. Snažil sa interpretovat' nielen hodnotu integrálneho ukazovatel'a, ale aj vývojový trend, ktorý by umožnil presnejšie predikovat' budúce smerovanie podnikatel'ského subjektu. Tafflerov bankrotný model pracuje s nasledujúcimi štyrmi ukazovatel'mi (Taffler, Tseung, 1984):

$\mathrm{x}_{1}=\mathrm{EBT} /$ krátkodobé záväzky,

$$
T B M=0,53 * x_{1}+0,13 * x_{2}+0,18 * x_{3}+0,16 * x_{4}
$$

$\mathrm{x}_{2}=$ obežný majetok/cudzí kapitál,

$\mathrm{x}_{3}=$ krátkodobé záväzky/majetok,

$\mathrm{x}_{4}=$ tržby/majetok.

Podniky, ktorých výsledná hodnota je väčšia ako 0,3 , sú zaradené do skupiny s malou pravdepodobnost'ou bankrotu (podnik považujeme za bonitný). Vysoké riziko bankrotu (v tomto prípade podnik považujeme za bankrotujúci) je charakteristické pre podniky, ktorých výsledná hodnota je menšia ako 0,2. 


\section{Springate model}

Další predikčný model vyvinul v rámci výskumného projektu Simon Fraser University v Kanade G. L. V. Springate. Jeho model vychádza z princípu integrálneho Altmanovho modelu, pričom model bol testovaný na vzorke 40 podnikov. $Z$ pôvodne devätnástich pomerových ukazovatel'ov boli pomocou diskriminačnej analýzy následne vybrané iba 4 ukazovatele (Sands, Springate, Turgut, 1983):

$$
S=1,03 * x_{1}+3,07 * x_{2}+0,66 * x_{3}+0,4 * x_{4}
$$

$\mathrm{x}_{1}=$ čistý pracovný kapitál/majetok,

$\mathrm{x}_{2}=$ zisk pred zdanením/majetok,

$\mathrm{x}_{3}=\mathrm{EBT} /$ krátkodobé záväzky,

$\mathrm{x}_{4}=$ tržby/majetok.

V prípade Springate modelu je deliacou hranicou 0,862. Ak podnik dosiahne hodnotu menšiu ako 0,862 , môžeme ho hodnotit' ako „failed“, t.j. v podniku sa očakávajú problémy.

\section{Index IN05}

Index IN05 predstavuje úpravu Altmanovej analýzy pre podmienky Českej republiky, pričom autormi indexu sú Neumaier a Neumaierová. Medzi základné výhody Indexu IN05 patrí, že má jednoznačne definované algoritmy vyčíslenia používaných ukazovatel'ov, má jednoduchý výpočet, dáva jednoznačné výsledky, pracuje s verejne dostupnými finančnými údajmi o podniku, môže byt' použitý nielen $\mathrm{v}$ prípade podnikov obchodovaných na kapitálovom trhu, ale aj pre ostatné podniky a je vhodným doplnkom paralelnej sústavy ukazovatel'ov finančno-ekonomickej výkonnosti (Neumaierová, Neumaier, 2008, s. 14). Index IN05 pozostáva z piatich ukazovatel'ov a má nasledovný tvar:

$$
\text { IN05 }=0,13 * x_{1}+0,04 * x_{2}+3,97 * x_{3}+0,21 * x_{4}+0,09 * x_{5},
$$

$\mathrm{x}_{1}=$ celkový kapitál/cudzí kapitál,

$\mathrm{x}_{2}=\mathrm{EBIT} /$ nákladové úroky,

$\mathrm{x}_{3}=\mathrm{EBIT} /$ celkový kapitál,

$\mathrm{x}_{4}=$ výnosy celkom/celkový kapitál,

$\mathrm{x}_{5}=$ obežné aktíva/krátkodobé záväzky v širšom zmysle

Podniku s hodnotou indexu vyššou ako 1,6 je predpovedané výborné finančné zdravie, podnik $\mathrm{s}$ hodnotou pod 0,9 smeruje $\mathrm{k}$ bankrotu, podnik $\mathrm{s}$ hodnotou medzi 0,9 a 1,6 sa nachádza v šedej zóne.

\section{Model Poznański}

Model Poznański je jedným z najznámejších predikčných model, ktorý bol navrhnutý pre podmienky pol'ských podnikatel'ských subjektov. Konštrukcia modelu je založená na štyroch finančných ukazovatel'och, pričom jeho účinnost' bola stanovená na úrovni 92,98 \% (Rolbecki, 2000, s. 22). Model Poznański má nasledujúci tvar (Bombiak, 2010):

$$
F D=3,562 * x_{1}+1,588 * x_{2}+4,288 * x_{3}+6,719 * x_{4}-2,368,
$$

$\mathrm{x}_{1}=$ čistý zisk/majetok,

$\mathrm{x}_{2}=($ obežné aktíva-zásoby)/krátkodobé záväzky,

$\mathrm{x}_{3}=$ stály majetok/celkový majetok,

$\mathrm{x}_{4}=$ zisk z predaja/ tržby z predaja.

Výsledná hodnota menšia ako 0 hovorí, že podniku hrozí zlá finančná situácia v budúcnosti. Ak podnik dosiahne hodnotu vyššiu ako 0 , môže v budúcnosti očakávat' priaznivú finančnú situáciu.

\section{Model Virag a Hajda}

Upravené predikčné modely pre mad'arské podniky nemajú v Mad'arsku dlhodobú tradíciu. Prvé bankrotné modely vytvorili Mikloš Virag a Otto Hajda, pričom sú založené 
na účtovných dátach mad’arských podnikov z roku 1990 a 1991. Do výberového súboru bolo zahrnutých 154 podnikov, z toho bolo 77 prosperujúcich podnikov a 77 bankrotujúcich podnikov. Na tvorbu modelu jeho autori použili 17 vstupných pomerových ukazovatel'ov, pričom výsledná rovnica obsahuje 4 finančné ukazovatele (Virag, Kristof, 2005, s. 407):

$$
Z=1,3566 * x_{1}+1,63397 * x_{2}+3,66384 * x_{3}+0,03366 * x_{4}
$$

$\mathrm{x}_{1}=$ okamžitá likvidita,

$\mathrm{x}_{2}=$ cash-flow/dlhy,

$\mathrm{x}_{3}=$ obežné aktíva/aktíva celkom,

$\mathrm{x}_{4}=$ cash-flow/aktíva celkom.

Deliacou hodnotou je v prípade modelu hodnota 2,61612. Podniky s vyššou hodnotou ako 2,61612 sú klasifikované ako solventné, nižšia hodnota hovorí o riziku úpadku podniku.

\section{Ohlsonov model}

Ohlsonov model (logit model), ktorý sa nazýva aj tzv. O-skóre bol navrhnutý v roku 1980 Jamesom Ohlsonom (Ohlson, 1980, s. 131). Autor aplikoval logistickú regresnú analýzu na vzorke 105 zbankrotovaných a 2058 prosperujúcich priemyselných podnikoch počas rokov 1970 - 1976 (Cisko, Vašiček, 2012, s. 77). Model má nasledujúci tvar (Wang, 2010):

$$
\begin{aligned}
& O=-1,32-0,407 * x_{1}+6,03 * x_{2}-1,43 * x_{3}-0,0757 * x_{4}-2,37 * x_{5}-1,83 * x_{6}+0,285 * x_{7} \\
& -1,72 * x_{8}-0,521 * x_{9},
\end{aligned}
$$

pravdepodobnost' bankrotu $=\frac{e^{0}}{1+e^{0}}$,

$\mathrm{x}_{1}=\log$ (celkové A/deflátor HDP),

$\mathrm{x}_{2}=($ cudzie zdroje - rezervy)/celkové A,

$\mathrm{x}_{3}=\check{\mathrm{CPK}} /$ celkové A,

$\mathrm{x}_{4}=$ krátkodobé rezervy/obežné A,

$\mathrm{x}_{5}=\mathrm{EAT} /$ celkové A,

$\mathrm{x}_{6}=\mathrm{EBITDA} /($ cudzie zdroje - rezervy),

$\mathrm{x}_{7}=1$ ak EAT $<0 \mathrm{v}$ posledných dvoch rokoch; inak 0 ,

$\mathrm{x}_{8}=1$ ak (cudzie zdroje - rezervy) $>$ celkové aktíva; inak 0 ,

$\mathrm{X}_{9}=\frac{E A T t-E A T t-1}{|E A T| t+|E A T| t-1}$.

\section{Zmijewski model}

Zmijewski model patrí k tzv. probit modelom. Probit analýza je alternatívnou štatistickou metódou k logit metóde. Je vel'mi podobná s hlavným rozdielom, že predpokladá normálne rozdelenie náhodných veličín (nezávislých premenných v modeli). Autorom modelu je Mark E. Zmijewski, ktorý do svojho modelu zahrnul 40 bankrotujúcich podnikov a 800 finančne zdravých podnikov. Môžeme vidiet', že rovnost' kovariančných matíc, ktorá sa vyžaduje pri viacrozmernej diskriminačnej analýze, nie je v modeli dodržaná. Danú skutočnost' autor argumentu tým, že takýto výber podnikov je pre zostavenie modelu vhodnejší, ked’že bankrotujúcich podnikov je v spoločnosti relatívne málo - okolo $0,75 \%$. Preto považuje za nesprávne, aby vo vzorke pre výpočet modelu bolo až okolo $50 \%$ bankrotujúcich podnikov (Cisko, Vašiček, 2012, s. 80). Rovnica Zmijewskeho modelu je nasledovná:

$$
Z m=-4,336-4,513 * x_{1}+5,679 * x_{2}+0,004 * x_{3},
$$

pravdepodobnost' bankrotu $=\frac{1}{1+e^{-Z m}}$,

$\mathrm{x}_{1}=\mathrm{EAT} /$ celkové aktíva,

$\mathrm{x}_{2}=$ cudzie zdroje/celkové aktíva,

$\mathrm{x}_{3}=$ obežné aktíva/krátkodobé záväzky. 
V druhej časti predloženého príspevku, pred začiatkom verifikácie metód, budú podnikatel'ské subjekty rozdelené do kategórie prosperujúcich, resp. neprosperujúcich podnikov na základe výsledku ukazovatel'a ekonomická pridaná hodnota (EVA - Economic Value Added). EVA je považovaná za súhrnnú charakteristiku finančnej výkonnosti podniku. Ukazovatel' vyjadruje tzv. nadzisk podniku, pričom vychádza z pravidla, že podnik musí vyprodukovat' minimálne taký objem, aký predstavujú náklady investovaného kapitálu. V prípade ak podnikatel'ský subjekt dosiahol hodnotu väčšiu ako 0 bol zaradený do skupiny prosperujúcich podnikov, ked'že svojou činnost'ou tvoril hodnotu. Pre neprosperujúce podniky je charakteristická negatívna hodnota ukazovatel'a EVA, pričom podnikatel'ský subjekt v tomto prípade hodnotu „Zničil“".

\section{Verifikácia výsledkov vybraných metód predikcie}

Vyššie charakterizovaných desat' predikčných metód bolo aplikovaných na šiestich slovenských podnikatel'ských subjektoch. Štyri podnikatel'ské subjekty (SB INMART, a.s.; ZTS strojárne, s.r.o., Edilan, s.r.o., Kovofinál, s.r.o.) majú výrobný charakter a dva podnikatel'ské subjekty (Spirit, s.r.o. a Podhájska, s.r.o.) sú z oblasti služieb. Detailnejšiu charakteristiku podnikov znázorňuje nasledovná tabul'ka číslo 1.

Tabul'ka 1: Charakteristika analyzovaných podnikov

\begin{tabular}{|l|c|c|c|}
\hline Názov podniku & Vel'kost' podniku & Samosprávny kraj & SK NACE \\
\hline Spirit, s.r.o. & Mikropodnik & Banskobystrický kraj & $\begin{array}{c}\text { F-Stavebníctvo } \\
\text { Podhájska, s.r.o. }\end{array}$ \\
Malý podnik & Nitriansky kraj & $\begin{array}{c}\text { R-Športové, zábavné } \\
\text { a vol'no časové aktivity }\end{array}$ \\
\hline SB INMART, a.s. & Stredný podnik & Žilinský kraj & C-Priemysel \\
\hline ZTS strojárne, s.r.o. & Vel'ký podnik & Žilinský kraj & C-Priemysel \\
\hline Edilan, s.r.o. & Malý podnik & Trenčiansky kraj & C-Priemysel \\
\hline Kovofinál, s.r.o. & Malý podnik & Trenčiansky kraj & C-Priemysel \\
\hline
\end{tabular}

Zdroj: Internetové stránky analyzovaných podnikov

Účtovné výkazy analyzovaných podnikov predstavovali zdrojovú základňu údajov pri výpočtoch predikčných metód. Konkrétne išlo o súvahu a výkaz ziskov a strát za účtovné obdobie 2009, 2010 a 2011. V prípade Ohlsonovho modelu bolo potrebné použit' aj výkaz ziskov a strát z roku 2008, ked’že pri výpočte ukazovatel'a

$$
x_{9}=\left(\frac{E A T t-E A T t-1}{\|E A T|t+\| E A T| t-1}\right),
$$

je potrebné poznat' čistý zisk za predchádzajúce účtovné obdobie.

Z odbornej literatúry je zrejmé, že predikčné metódy majú rôzne bodovacie/hodnotiace stupnice a škály, a preto ich výsledná interpretácia o budúcej finančnej situácii nie je totožná Pre potrebu jednoduchšej orientácie a porovnatel'nosti sme sa rozhodli použit' nasledovné tri podoby výsledkov predikčných metód:

- prosperujúci podnik ( $\mathrm{v}$ tabul'ke číslo 2 a 3 uvedené pros.) - v prípade, že v budúcnosti môže podnik očakávat' dobré finančné zdravie s malou pravdepodobnost'ou bankrotu,

- neprosperujúci podnik ( $\mathrm{v}$ tabul'ke číslo 2 a 3 uvedené nepros.) - v prípade, že v budúcnosti môže podnik očakávat' finančné t’ažkosti a jeho pravdepodobnost' bankrotu je vysoká,

- Šedá zóna - nevyhranená finančná situácia, podnik nepatrí ani do skupiny prosperujúcich podnikov, ale ani do skupiny neprosperujúcich podnikov. 
Tabul'ka 2: Výsledky metód predikcie v podnikoch služieb v rokoch 2009, 2010, 2011

\begin{tabular}{|l|c|c|c|c|c|c|}
\hline \multirow{2}{*}{} & \multicolumn{3}{|c|}{ Spirit, s.r.o. } & \multicolumn{3}{c|}{ Podhájska, s.r.o. } \\
\cline { 2 - 7 } & $\mathbf{2 0 0 9}$ & $\mathbf{2 0 1 0}$ & $\mathbf{2 0 1 1}$ & $\mathbf{2 0 0 9}$ & $\mathbf{2 0 1 0}$ & $\mathbf{2 0 1 1}$ \\
\hline Rýchly test & pros. & pros. & pros. & pros. & pros. & pros. \\
\hline Altmanovo Z-skóre & pros. & pros. & pros. & pros. & pros. & pros. \\
\hline Index bonity & pros. & pros. & pros. & pros. & pros. & pros. \\
\hline TBM & pros. & pros. & pros. & pros. & pros. & pros. \\
\hline Springate model & pros. & pros. & pros. & pros. & nepros. & pros. \\
\hline IN05 & pros. & pros. & pros. & pros. & pros. & sedá zóna \\
\hline Poznański model & pros. & pros. & pros. & pros. & pros. & pros. \\
\hline Virag a Hajda & pros. & pros. & pros. & pros. & nepros. & nepros. \\
\hline Ohlsonov model & pros. & pros. & pros. & pros. & pros. & pros. \\
\hline Zmijewski model & pros. & pros. & pros. & pros. & pros. & pros. \\
\hline Prosperujúci & $100 \%$ & $100 \%$ & $100 \%$ & $100 \%$ & $80 \%$ & $80 \%$ \\
\hline Neprosperujúci & $0 \%$ & $0 \%$ & $0 \%$ & $0 \%$ & $20 \%$ & $10 \%$ \\
\hline Šedá zóna & $0 \%$ & $0 \%$ & $0 \%$ & $0 \%$ & $0 \%$ & $10 \%$ \\
\hline
\end{tabular}

Zdroj: Spracované na základe výpočtov z interných materiálov analyzovaných podnikov

Z dôvodu rozsiahlosti a vel'kého množstva údajov sme rozdelili výsledky vybraných predikčných metód. V tabul'ke číslo 2 sú znázornené výstupy metód predikcie podnikov, ktoré pôsobia v oblasti služieb (Spirit, s.r.o. a Podhájska, s.r.o.). Tabul'ka číslo 3 prezentuje výstupy predikčných metód vo výrobných podnikoch (SB INMART, a.s. a ZTS strojárne, s.r.o.). V závere každej tabul'ky (posledné tri riadky tabul'ky) uvádzame, kol'ko percent z desiatich predikčných metód vo vybranom roku $(2009,2010$ alebo 2011) zaradilo analyzovaný podnik do jednej z troch kategórií (prosperujúci podnik, neprosperujúci podnik alebo šedá zóna). Môžeme teda tvrdit', že ide o tzv. percentuálne vyjadrenie zhody predikčných metód.

V tabul'ke číslo 2 vidíme, že v podniku Spirit, s.r.o. všetky použité predikčné metódy dosiahli vo všetkých troch analyzovaných rokoch 100 percentnú zhodu, a teda zvolených 10 metód predikcie zaradilo podnik Spirit, s.r.o. v roku 2009, 2010 aj v roku 2011 medzi prosperujúce podniky. V podniku Podhájska, s.r.o. bola dosiahnutá 100 percentná zhoda iba v roku 2009 (podnik bol zaradený medzi prosperujúce podniky všetkými desiatimi metódami). V rokoch 2010 a 2011 bol daný podnik klasifikovaný ako prosperujúci na základe ôsmych predikčných metód ( $\mathrm{v}$ roku 2010 Springate model a model Virag a Hajda zaradili podnik k neprosperujúcim podnikom; v roku 2011 Index IN05 zaradil termálne kúpalisko Podhájska, s.r.o. do šedej zóny a model Virag a Hajda ho identifikoval ako neprosperujúci podnik). Predikčné metódy sú dnes mnohokrát vystavené kritike zo strany akademickej obce i zo strany finančných manažérov a analytikov, čo je spôsobené najmä pretrvávajúcou finančnou krízou. I napriek tejto skutočnosti môžeme konštatovat', že na základe výpočtov a výsledkov metód predikcie bola dosiahnutá v nami analyzovaných podnikoch služieb vysoká miera zhody. 
Tabul'ka 3: Výsledky metód predikcie vo výrobných podnikoch v rokoch 2009, 2010, 2011

\begin{tabular}{|l|c|c|c|c|c|c|}
\hline \multirow{2}{*}{} & \multicolumn{3}{|c|}{ SB INMART, a.s. } & \multicolumn{3}{c|}{ ZTS strojárne, s.r.o. } \\
\cline { 2 - 7 } & $\mathbf{2 0 0 9}$ & $\mathbf{2 0 1 0}$ & $\mathbf{2 0 1 1}$ & $\mathbf{2 0 0 9}$ & $\mathbf{2 0 1 0}$ & $\mathbf{2 0 1 1}$ \\
\hline Rýchly test & nepros. & šedá zóna & pros. & nepros. & pros. & pros. \\
\hline Altmanovo Z-skóre & nepros. & šedá zóna & šedá zóna & šedá zóna & šedá zóna & šedá zóna \\
\hline Index bonity & nepros. & šedá zóna & pros. & nepros. & pros. & pros. \\
\hline TBM & nepros. & pros. & pros. & šedá zóna & pros. & pros. \\
\hline Springate model & nepros. & pros. & pros. & nepros. & nepros. & nepros. \\
\hline IN05 & nepros. & šedá zóna & šedá zóna & nepros. & šedá zóna & šedázóna \\
\hline Poznański model & nepros. & pros. & pros. & nepros. & pros. & pros. \\
\hline Virag a Hajda & nepros. & pros. & pros. & nepros. & pros. & pros. \\
\hline Ohlsonov model & nepros. & pros. & pros. & pros. & pros. & pros. \\
\hline Zmijewski model & nepros. & pros. & pros. & pros. & pros. & pros. \\
\hline \hline Prosperujúci & $0 \%$ & $60 \%$ & $80 \%$ & $20 \%$ & $70 \%$ & $70 \%$ \\
\hline Neprosperujúci & $100 \%$ & $0 \%$ & $0 \%$ & $60 \%$ & $10 \%$ & $10 \%$ \\
\hline Šedá zóna & $0 \%$ & $40 \%$ & $20 \%$ & $20 \%$ & $20 \%$ & $20 \%$ \\
\hline
\end{tabular}

Zdroj: Spracované na základe výpočtov z interných materiálov analyzovaných podnikov

Výsledky predikčných metód v nami analyzovaných výrobných podnikatel'ských subjektoch SB INMART, a.s. a ZTS strojárne, s.r.o. nie sú až také jednoznačné, ako to bolo v prípade podnikov služieb, čo znázorňuje aj tabul'ka číslo 3. Sto percentná zhoda bola dosiahnutá iba v podniku SB INMART, a.s., ked' v roku 2009 všetkých desat' predikčných metód klasifikovalo daný podnik ako neprosperujúci. V roku 2010 bol dosiahnutý v podniku SB INMART, a.s. najväčší nesúlad vo výsledkoch metód predikcie. Rýchly test, Altmanovo Zskóre, Index bonity a Index IN05 zaradili podnik do šedej zóny a ostatných šest' predikčných metód ho klasifikovalo ako prosperujúci. Na základe výsledkov ôsmych metód predikcie bol podnik SB INMART, a.s. v roku 2011 charakterizovaný ako prosperujúci (Altmanovo Zskóre a Index IN05 ho zaradili do šedej zóny).

V nasledujúcej tabul'ke 4 môžeme vidiet', že v podnikoch Edilan, s.r.o. a Kovofinál, s.r.o. bola dosiahnutá zhoda vo všetkých troch analyzovaných rokoch, ked’že všetkých 10 metód predikcie zaradilo dané podniky do skupiny neprosperujúcich podnikov.

Tabul'ka 4: Výsledky metód predikcie vo výrobných podnikoch v rokoch 2009, 2010, 2011

\begin{tabular}{|l|c|c|c|c|c|c|}
\hline \multirow{2}{*}{} & \multicolumn{3}{|c|}{ Edilan, s.r.o. } & \multicolumn{3}{c|}{ Kovofinál, s.r.o. } \\
\cline { 2 - 7 } & $\mathbf{2 0 0 9}$ & $\mathbf{2 0 1 0}$ & 2011 & 2009 & 2010 & 2011 \\
\hline Rýchly test & nepros. & nepros. & nepros. & nepros. & nepros. & nepros. \\
\hline Altmanovo Z-skóre & nepros. & nepros. & nepros. & nepros. & nepros. & nepros. \\
\hline Index bonity & nepros. & nepros. & nepros. & nepros. & nepros. & nepros. \\
\hline TBM & nepros. & nepros. & nepros. & nepros. & nepros. & nepros. \\
\hline Springate model & nepros. & nepros. & nepros. & nepros. & nepros. & nepros. \\
\hline IN05 & nepros. & nepros. & nepros. & nepros. & nepros. & nepros. \\
\hline Poznański model & nepros. & nepros. & nepros. & nepros. & nepros. & nepros. \\
\hline Virag a Hajda & nepros. & nepros. & nepros. & nepros. & nepros. & nepros. \\
\hline Ohlsonov model & nepros. & nepros. & nepros. & nepros. & nepros. & nepros. \\
\hline Zmijewski model & nepros. & nepros. & nepros. & nepros. & nepros. & nepros. \\
\hline Prosperujúci & $0 \%$ & $0 \%$ & $0 \%$ & $0 \%$ & $0 \%$ & $0 \%$ \\
\hline Neprosperujúci & $100 \%$ & $100 \%$ & $100 \%$ & $100 \%$ & $100 \%$ & $100 \%$ \\
\hline Šedá zóna & $0 \%$ & $0 \%$ & $0 \%$ & $0 \%$ & $0 \%$ & $0 \%$ \\
\hline
\end{tabular}

Zdroj: Spracované na základe výpočtov z interných materiálov analyzovaných podnikov 
Súčasná situácia vo svetovom hospodárstve spôsobila, že metódy predikcie strácajú svoju vypovedaciu schopnost' v porovnaní s minulost'ou. Táto skutočnost' je ovplyvnená aj narastajúcou úrovňou rizík, ktoré sú dôsledkom stále pretrvávajúcej hospodárskej krízy. Niektoré zmeny sú tak razantné, že dôsledkom nich prestávajú platit' mnohé postuláty, na ktorých bola doteraz ekonomická teória postavená a podnikatel'ské subjekty sú nútené pohybovat' sa v novom prostredí. V súčasnom období prudko sa meniaceho prostredia je preto spol'ahlivost' a vypovedacia schopnost' predikčných metód finančnej analýzy ex-ante viac než problematická. Úradníček (2010) uvádza, že jednou z príčin je skutočnost', že príznaky, ktoré by sme mohli odhalit' $\mathrm{v}$ historických časových radoch nemajú kontinuálnu prolongáciu do súčasnosti.

Na základe vyššie uvedených skutočností sme sa rozhodli výsledky desiatich predikčných metód verifikovat'. Pod verifikáciu metód rozumieme testovanie správneho zaradenia podnikov, t.j. prosperujúce podniky by mali byt' na základe výsledkov predikčných metód zaradené do skupiny prosperujúcich podnikov a bankrotujúce podniky by mali byt' zaradené do skupiny bankrotujúcich podnikov. Verifikácia bude uskutočnené retrospektívne, pričom budeme vychádzat' z výsledkov predikčných metód v roku 2011.

$\mathrm{Na}$ základe výsledkov ukazovatel’a EVA boli prvé štyri podniky nachádzajúce sa v analyzovanom súbore zaradené do skupiny prosperujúcich podnikov, t.j. hodnota ukazovatel'a EVA bola vo všetkých prípadoch vyššia ako 0 . Z uvedenej skutočnosti vyplýva, že predikčné metódy finančnej analýzy ex-ante by mali v roku 2011 dané podnikatel'ské subjekty klasifikovat' ako prosperujúce s malou pravdepodobnost'ou bankrotu. Podnikatel'ské subjekty Edilan, s.r.o. a Kovofinál, s.r.o. boli na základe výsledkov ukazovatel'a EVA klasifikované ako neprosperujúce podniky, ked’že hodnota daného ukazovatel'a bola negatívna. Samozrejme, je potrebné zdôraznit', že primárnou funkciou metód predikcie je upozornit' na negatívnu situáciu podniku a jeho možný úpadok v budúcnosti. Ovel’a negatívnejší dopad má nesprávne zaradenie neprosperujúcich podnikov, kedy sú dané podniky identifikované ako prosperujúce, t.j. podniky nemôžu uskutočnit' ozdravné opatrenia v dostatočnom časovom predstihu. Výstupy vybraných desiatich metód predikcie za rok 2011 komplexne prezentujeme v nasledujúcej tabul'ke číslo 5.

Tabul'ka 5: Výsledky predikčných metód vo vybranej skupine podnikov v roku 2011

\begin{tabular}{|l|c|c|c|c|c|c|}
\hline & $\begin{array}{c}\text { Spririt, } \\
\text { s.r.o. }\end{array}$ & $\begin{array}{c}\text { Podhájska, } \\
\text { s.r.o. }\end{array}$ & $\begin{array}{c}\text { SB } \\
\text { INMART, } \\
\text { a.s. }\end{array}$ & ZTS, s.r.o. & $\begin{array}{c}\text { Edilan, } \\
\text { s.r.o. }\end{array}$ & $\begin{array}{c}\text { Kovofinál, } \\
\text { s.r.o. }\end{array}$ \\
\hline Rýchly test & pros. & pros. & pros. & pros. & nepros. & nepros. \\
\hline Altmanovo Z-skóre & pros. & pros. & šedá zóna & šedá zóna & nepros. & nepros. \\
\hline Index bonity & pros. & pros. & pros. & pros. & nepros. & nepros. \\
\hline TBM & pros. & pros. & pros. & pros. & nepros. & nepros. \\
\hline Springate model & pros. & pros. & pros. & nepros. & nepros. & nepros. \\
\hline IN o5 & pros. & šedá zóna & šedá zóna & šedá zóna & nepros. & nepros. \\
\hline Poznański model & pros. & pros. & pros. & pros. & nepros. & nepros. \\
\hline Virag a Hajda & pros. & nepros. & pros. & pros. & nepros. & nepros. \\
\hline Ohlsonov model & pros. & pros. & pros. & pros. & nepros. & nepros. \\
\hline Zmijewski model & pros. & pros. & pros. & pros. & nepros. & nepros. \\
\hline
\end{tabular}

Zdroj: Spracované na základe výpočtov z interných materiálov podnikov 
Vo vyššie uvedenej tabul'ke sú zvýraznené nesprávne výsledky predikčných metód. Vidíme, že v danom súbore šiestich podnikatel'ských subjektov dosiahli vybrané predikčné metódy pomerne vysokú vypovedaciu (predikčnú) schopnost'. Na základe výsledkov Rýchleho testu, Indexu bonity, Tafflerovho bankrotného modelu, modelu Poznański, Ohlsonovho modelu a modelu Zmijewski boli všetky podnikatel'ské subjekty zaradené správne (t.j. do kategórie prosperujúcich podnikov). Altmanovo Z-skóre zaradilo v roku 2011 dva podniky do šedej zóny a výsledky Indexu IN05 taktiež zaradili podniky Podhájska s.r.o., SB INMART, a.s. a ZTS strojárne, s.r.o. do tejto kategórie. V tabul'ke vidíme, že oba neprosperujúce podniky boli na základe 10 metód predikcie zaradené správne, t.j. do kategórie neprosperujúcich podnikov. Danú skutočnost' hodnotíme pozitívne. V nasledujúcom obrázku uvádzame predikčnú schopnost' vybraných 10 metód predikcie na nami analyzovanej vzorke podnikov.

Obrázok 1: Predikčná schopnost' vybraných metód finančnej analýzy ex-ante

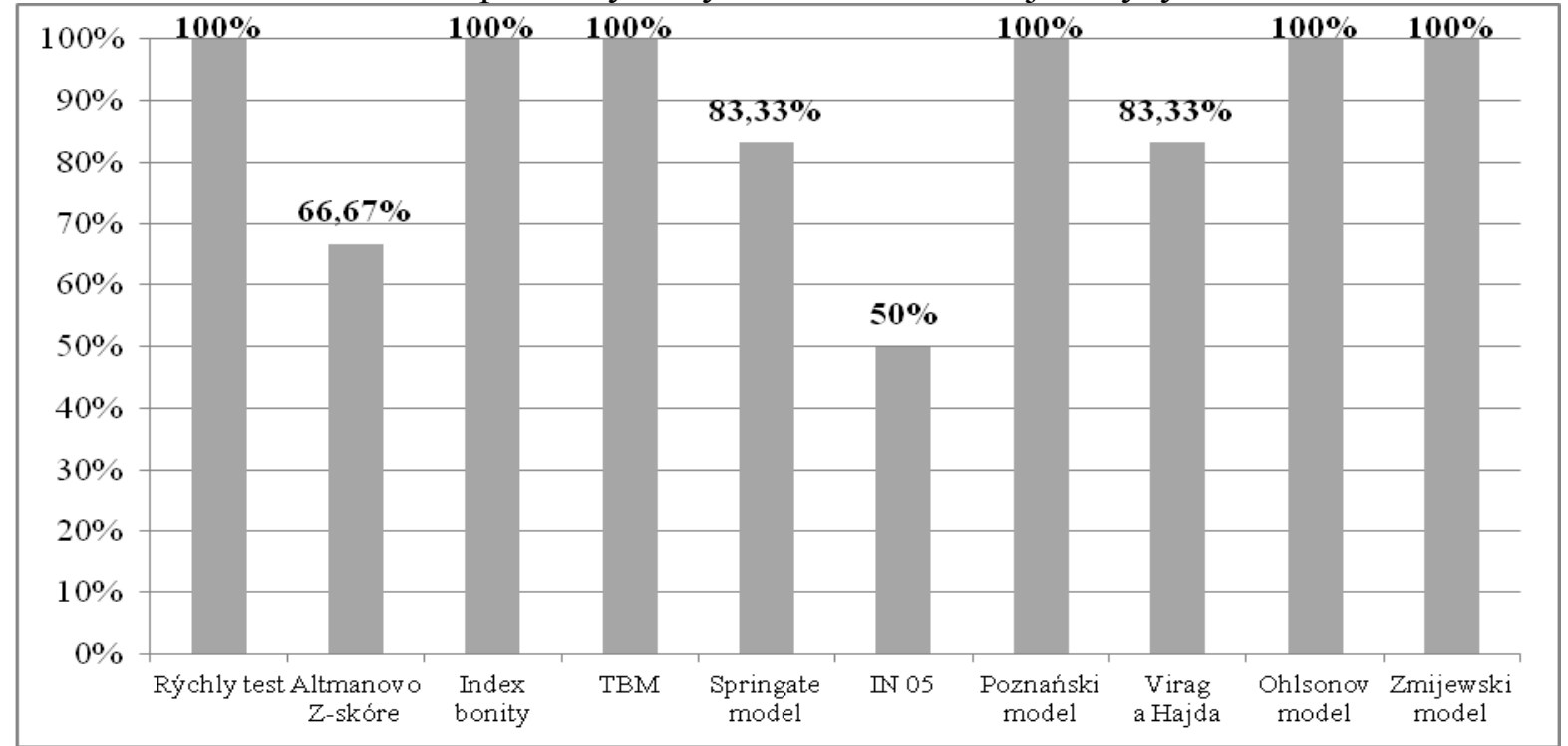

Zdroj: Spracované na základe výpočtov z interných materiálov podnikov

Na obrázku vidíme, že predikčná schopnost' sa pohybovala v rozmedzí od $50 \%$ do $100 \%$, pričom najhoršiu predikčnú schopnost' dosiahol Index IN05, ktorý správne zaradil iba polovicu podnikatel'ských subjektov.

\section{Záver}

Po ekonomickom útlme z rokov 2008 - 2009 a následnom čiastočnom ozdravení odborná verejnost' riešila otázku, či má svetová kríza charakter tzv. dvojitého $\mathrm{W}$, teda či môžeme opät' očakávat' zhoršenie ekonomických podmienok. V súčasnej dobe globálna ekonomika opät' spomal'uje a mnohé krajiny v Európskej únii prechádzajú recesiou. Okrem toho, ako uvádza Smutný (2013) globálna finančná kríza v priebehu piatich rokov prerástla do krízy dlhodobej, ktorá d’alej negatívne ovplyvňuje očakávania ekonomických subjektov, odrádza podniky od investícií a prijímania zamestnancov, obyvatel'stvo od vyššej spotreby a tým d'alej spomal'uje ozdravný ekonomický proces.

Jedným z dôsledkov súčasnej situácie je aj zlyhanie podnikatel'ských subjektov. Na tomto mieste vystupuje do popredia význam predikčných metód, ktoré dokážu okrem identifikovania kritických aspektov, ktoré by mohli ohrozit' existenciu podniku v budúcnosti, oklasifikovat' podnik iba jednou známkou. Táto skutočnost' je ich významnou silnou stránkou, nakol'ko finančný manažér získa komplexný pohl’ad na finančnú situáciu jeho podniku. Rovnako sa finančnou analýzou ex-ante odstraňujú aj nevýhody metód finančnej analýzy ex- 
post. Na druhej strane súčasná situácia v podnikatel'skom prostredí upozorňuje na skutočnost', že aplikácia predikčných metód finančnej analýzy ex-ante je vel'mi citlivou záležitost'ou, pri ktorej musí finančný manažér brat’ do úvahy celý rad rôznych interných i externých faktorov.

Ciel'om predloženého príspevku bolo porovnat' výsledky vybraných predikčných metód a následne verifikovat' ich vypovedaciu schopnost'. I napriek občasnému kritickému pohl'adu na predikčné metódy hodnotíme výsledky praktickej aplikácie predikčných metód v rokoch 2009, 2010 a 2011 v analyzovanom súbore šiestich podnikov vysoko pozitívne. Výsledky uskutočnenej verifikácie môžeme rovnako zhodnotit' kladne, ked'že Rýchly test, Index bonity, Tafflerov bankrotný model, model Poznański, Ohlsonov model a model Zmijewski dosiahli $100 \%$ - tnú predikčnú schopnost'. Je potrebné zdôraznit', že zámerom príspevku bolo znázornit' metodický postup komparácie a verifikácie metód predikcie a dosiahnuté výstupy sú charakteristické iba pre danú vzorku šiestich slovenských podnikatel'ských subjektov. Túto skutočnost' potvrdzuje aj fakt, že na nami analyzovanej vzorke dosiahol Index IN05 najhoršiu vypovedaciu schopnost' (50 \%), pričom z výsledkov poslednej verifikácie vyplynulo, že Index IN05 zaradil správne 63,89\% neprosperujúcich podnikov (v čase jeho vzniku $77 \%$ ) a taktiež klasifikoval správne $81,77 \%$ prosperujúcich podnikov (v čase jeho vzniku $88 \%$ ) (Neumaierová, Neumaier, 2013). Na záver môžeme konštatovat', že verifikácia predikčných metód je v značnej miere ovplyvnená štruktúrou a vel'kost'ou výberovej vzorky podnikov.

\section{Literatúra}

[1] BARDÚN, A., 2010. Kapitálová přměrenost, Basel II a modely predikce defaultu. Dizertačná práca. [CD]. [vid. 2013-21-05]. Praha: Podnikohospodárska fakulta, Vysoká škola Ekonomická.

[2] BOMBIAK, E., 2010. Modele dyskryminacyjne jako metody oceny sytuacji finansowej prsedsi biorstvwa. Zeszyty Naukowe Akademii Podlaskiej w Siedlcach, 86(13), 141-152. ISSN 2082-5501.

[3] CISKO, Š. a M. VAŠANIČ, 2012. Predikcia rizika zlyhania podnikatel'ských subjektov pomocou logistickej regresie. Podniková ekonomika a manažment, 2, 76-86. ISSN 13365878 .

[4] LESÁKOVÁ, L., 2004. Metódy hodnotenia výkonnosti malých a stredných podnikov. Banská Bystrica: Univerzita Mateja Bela. ISBN 80-8055-914-7.

[5] LESÁKOVÁ, L. A KOL., 2007. Finančno-ekonomická analýza podniku. Banská Bystrica: Univerzita Mateja Bela, Ekonomická fakulta. ISBN 978-80-8083-379-4.

[6] NEUMAIEROVÁ, I. a I. NEUMAIER, 2008. Proč se ujal index IN a nikoli pyramídový systém ukazatelů INFA. Ekonomika a management, 2(4), 12-19. ISSN 1802-8470.

[7] NEUMAIEROVÁ, I. a I. NEUMAIER, 2013. Vypovídací schopnost Indexu IN05. In: Ekonomika $v$ pohybu - sbornik príspěvků $z$ mezinárodni conference poŕádané $u$ př́ležitosti šedesáteho výroči VŠE a fakulty. [CD]. Praha: Vysoká škola ekonomická v Praze, Nakladatelství Oeconomica. ISBN 978-80-245-1943-2.

[8] NOVÝ, P., 2011. Finanční informatika a analýz [online]. [vid. 20.05.2013]. Dostupné z: http:/www.kiv.zcu.cz/\%Enovyp/fia/fia.html

[9] OHLSON, J., 1980. Financial ratios and the probabilistic prediction of bankruptcy. Journal of Accounting Research, 18(1), 109-131. ISSN 1475-679X. 
[10]ROLBECKI, R., 2000. Analiza dyskryminacji w ocenie sytuacji finansowej przedsiębiorstw. Ekonomika i Organizacja Przedsiębiorstwa, 9(22). ISSN 0860-6846.

[11] SANDS, E. G., G. L. V. SPRINGATE a V. TURGUT, 1983. Predicting Business Failures. CGA Magazine, 24-27. ISSN 0318-742X.

[12] SMUTNÝ, P., 2013. Čas na restrukturalizaci. Finanční manažment, 10(4), 8-10. ISSN 1214-9292.

[13] TAFFLER, R. J. a M. TSEUNG, 1984. The Audit Going-Concern In Practise. Accountant's Magazine, 88, 263-269. ISSN 0001-4761.

[14]ÚRADNÍČEK, V., 2010. Alternatívne metódy hodnotenia výkonnosti podniku. Habilitačná práca. [CD]. [vid. 2013-08-01]. Banská Bystrica: Ekonomická fakulta Univerzita Mateja Bela.

[15] VIRAG, M. a T. KRISTOF, 2005. Neural networks in bankruptcy prediction - A comparative study on the basis of the first Hungarian bankruptcy model. Acta Oeconomica, 55(4), 403-425. ISSN 0001-6373.

[16] Vývoj konkurzov a reštrukturalizácií. Cribis.sk - Univerzálny register [online]. [vid. 16.12.2013]. Dostupné z: http://www.cribis.sk/Home.aspx

[17] WANG, Y., 2010. Financial ratios and the prediction of bankruptcy: The Ohlson model applied to chinese publicly trated companies. The Journal of Organizational Leadership and Business, 5(2), 1-15. ISSN 1048-9843.

[18] ZALAI, K. A KOL., 2008. Finančno-ekonomická analýza podniku. Bratislava: Sprint vfra. ISBN 80-8908-599-6. 